\title{
The Effects of COVID-19 Pandemic on Service Sector Branding Tendency: Evidence from Turkey
}

\author{
Hale ALAN ${ }^{1}$, Ali Rıza KÖKER ${ }^{2} \odot$
}

\begin{abstract}
The service sector is becoming an increasingly important sector in most economies. Service marks, as an indicator of service innovations, are increasing worldwide. As with all industries and activities, the service sector has been affected by the Coronavirus 2019 (COVID-19) pandemic. This research aimed to analyze the effects of the COVID-19 pandemic on the service sector by using trademark application data. In particular, textual databases provide researchers with a rich wealth of information. Research was based on Turkish service mark applications belonging to the datasets comprise 264,000 lines in total (for the years 2016 to 2020). In addition, 114 search terms, which were determined with the help of service mark classifications according to International Nice Trademark Classification, were analyzed using the text mining method which is the sub-branch of data mining. According to the research results, a certain amount of service-related trademarks were not affected during the pandemic process; however, a change in the trademark's content applications was experienced. The main service classes having an increase in brand orientation during the pandemic were found to be services related to logistics, cleaning, hobby activities, distance education, and learning and storage services. On the other hand, real estate, tourism, cultural services, and health and legal services were the negatively influenced sectors.
\end{abstract}

Key Words: COVID-19, Service Sector, Pandemic, Branding, Service Marks, Trademarks

\section{Introduction}

The new type of coronavirus (COVID-19), emerged on December 1, 2019, in Wuhan, China, has been rapidly spreading throughout the world. As a result, the World Health Organization (WHO) has officially declared this global epidemic as pandemic on March 11, 2020. This epidemic has both economic and social impacts in our country as well as in the rest of the world. Having the whole world under its influence, the COVID-19 epidemic has changed our social and economic life, our habits and ways of doing business. The economic and social effects of the pandemic are different for every sector and every region. Its highest impact can be easily observed in the service sector. For example, while some services such as tourism-related transportation, hotels or food services have faced a complete breakdown of demand, some services like postal services, online shopping services or insurance services have faced increased demand. Since the service sector could not be able to provide their proper services as it used to be, one can easily argue that the most affected industry by the COVID-19 outbreak is the service sector. Although such an argument can be supported by several studies (Huang et al., 2020; Ramelli and Wagner, 2020; Gopinath, 2020), these studies are preliminary findings, and therefore more studies are required for better understanding.

On the other hand, the importance of the service sector for a country's economy and its impact on the growth rates is increasing every year. It can be seen that, within the economies of developed countries, the service sector has a priority and its share on economic indicators are quite high. For example, the service sector accounts for about two-thirds of employment and business activity in the OECD countries (Begg, 1993) Also the share of GDP originating from the service sector is 70-80 per cent for the developing countries (Ostrom et al., 2010). The service sector is becoming an increasingly important part of economies. Economic factors suggest that there is a positive relationship between economic factors, the evolution of economies, and the rise in services (Deloitte, 2018). As innovation is

1Akdeniz University, Department of Management Information Systems, Manavgat, Antalya, Turkey, e-mail: halealan@akdeniz.edu.tr,

${ }^{2}$ Turkish Patent and Trademark Office, Ankara, Turkey, e-mail: alikoker@gmail.com, 
a necessity for the firms that compete in environments where change is pervasive and unpredictable (Varoğlu \& Köker, 2009), it is a crucial issue in the service sector as well. In general, service innovations combine new processes with new technological options and new organisational arrangements (Flikkema et al., 2014). However, the evolvement of service innovations are issues that have not been dwelled upon in management literature, because of the attractiveness of the technology and product innovations due to more open access to these indicators for researchers to these indicators.

For years, innovation has been recognized by the majority as the key to economic growth. However, its role in the service sector has been undervalued due to limited and scarce data to measure innovation in the service sector. Indeed, specific indicators, which provide at least an indication of reality, is needed when measuring something that cannot be recognised directly (Gotsch \& Hipp, 2014). According to Schmoch (2003), traditional innovation studies in services have to cope with several problems, since it is challenging to classify subsectors of the service sector appropriately and it is expensive to collect data via time-consuming surveys. However, recent developments in the availability of digital databases make it possible to use trademark statistics as a new source of information in industrial and innovation studies (Mendonça et al., 2004). Having seen that there is a positive correlation between the trademark data and innovation (Schmoch and Gauch, 2009; Gotsch and Hipp, 2014; Flikkema et al., 2014), the popularity of using trademark data in studies is increasing. Analysis of trademark datasets provides a solution to overcome the current weaknesses of traditional innovation research and measurement concepts developed especially for the manufacturing industries (Hipp \& Grupp, 2005). Also, some sector-based studies focus on knowledge-intensive service sectors using trademark data as an indicator (Schmoch, 2003; Amara et al., 2008). Such researches show us trademark data is an excellent tool for measurement of service innovation. According to Gotsch and Hipp (2014), trademark dataset analysis can be used as an indicator of innovation and industry. By making such analysis, researchers can provide a feasible way to understand the trends in the market needs.

Companies have different branding strategies for goods and services. Although manufacturers and service providers may have many different targets, one of their common goals is to take advantage of the brand and branding which has become an essential part of economic life (Alan \& Yeloğlu, 2013). Branding is the focus of marketing activities that are directly related to consumer behaviours and separate products and services. The literature from different schools of theory has identified different motives such as economic, strategic or mimetic motives for trademark registration (Flikkema et al., 2014). For example, in economic theory, a company's decision to register a trademark may generally depend on the cost-benefit analysis; namely, the expected value of registration and the opportunity cost of the registration procedure is taken into account (Mendonça et al., 2004).

This article focuses on how service marks in the service sector have been changing due to COVID-19 pandemic. Although the production sectors have also been affected in the pandemic time, we route our primary focus to the service sectors due to not only its increase but also its interaction with a human, which makes the change in branding orientations more perceivable. At the same time, with this research, we aim to emphasise the importance of the return journey of service innovations to service marks in modern and advanced economies. In this regard, this study was conducted with the text mining method, which is the sub-branch of data mining, about how service innovations were shaped during crisis periods such as pandemics and their reflections on the service mark. The choice of terms or indicators of affected business areas in the service sector is based on the results of the literature review and research reports. By turning the pandemic into an opportunity, changes in service trademark applications made during the pandemic were tried to be determined.

This article tries to explain how the COVID-19 outbreak affected the service innovation and service trademarks orientations of the companies were studied. With this study, we argue that service trademark applications data are reflecting the right level of choices that can help to predict brand awareness strategies in times of crisis. In this context, research questions of the study are as follows;

RQ1: How did the pandemic affect service sector branding tendency?

RQ2: Which service mark classes were most affected during the pandemic?

RQ3: Which service innovations have appeared during the pandemic?

RQ4: Do the branding trends show parallelism with the sectors reflected in the economic indicators? 


\section{Theoretical Background}

\section{Service Sector and Service Innovations}

Since the 1970s, the decline in employment in the manufacturing industry has engendered increasing interest in the potential of the service sector to revitalise national and regional economies (Begg, 1993). The importance of the service sector in terms of its contribution to GDP and as a source of employment has continued to increase (Gerrath \& Leenders, 2013). With services creating most of the wealth and employment in advanced economies, fostering and managing service innovation exhibits unique challenges. Therefore, research on service innovation is getting increased attention in recent years, and the concept of service innovation is becoming multidimensional.

Chaston (2017) mentions about four main differences of services from production that are intangibility, heterogeneity, perishability and simultaneous production and consumption. One of the consequences of these differences is managing the fluctuations in supply and demand requires new approaches in the management of services. Therefore, innovation is also important for the service sector, as well. Since innovation is also important in the service sector, such firms belonging to this sector should pay attention to this issue. In order to maintain or increase their performance, organisations must continuously create new services, and for this, they need well-developed innovation capabilities (Gryszkiewicz et al., 2013). Service innovation has become a term referring to the innovation taking place in the various contexts of services, including the introduction of new services or incremental improvements of existing services (Durst et al., 2015). Service innovation can be defined as the creation of new value propositions through developing existing or creating new practices or through integrating practices and resources in new ways (Skålén et al., 2014). Service innovations comprise the introduction of new services, both dependent or independent from without the development of new technical products or processes. In general, innovation in the service sector relies less on R\&D than in the manufacturing sector.

Customers play a relatively important role in the service innovation process (Johne \& Storey, 1998) and often, innovation emerges in service jobs (Den Hertog \& Bilderbeek, 1999). In such cases, service firms try to commoditise new work practices, methods and tools which might be supported by trademark registrations (Flikkema et al., 2014). Various approaches to studying service sector innovation have been developed. In general, it is possible to say that the service sector refers to economic activities shaped by personal interactions which influence supplies and demands. Since it is important to manage fluctuations in supply and demand, service sector companies require new approaches about their business at such times. As COVID - 19 pandemic changes everything in our life, it can be taken as a source of supply and demand fluctuations. Therefore, service companies' innovative behaviours during pandemic stand as an important topic to study.

\section{Trademarks as an Indicator of Service Innovations}

A trademark is "a sign that individualises the goods of a certain business and distinguishes their products from the products of competitors" (WIPO, 2004, p. 54). According to this definition, trademarks fulfil two basic functions. First of all, trademarks present the market offers in connection to the firm that is responsible for placing the goods on the market. Secondly, trademarks point out to consumers that these offers are different from competing offers in the same market. As a trademark can be registered simply, and it allows a monopoly to the mark owner, the registration of a trademark must be included in every competition strategy for both well-established companies and newly established companies. According to one of the oldest definitions, Trademarks identify the origin of goods and services, thereby offering protection to both sellers and buyers (Greer, 1979). Trademarks are distinctive signs, used to differentiate between identical or similar goods and services provided by different producers or services providers (Birinci, 2009). With such a unique name or sign or symbol, consumers can identify a product or a service according to its nature or quality which meets their needs. Thus, a trademark may be considered as a tool of communication used by producers to attract consumers Trademark protection provides an opportunity to protect such names or signs against imitation. Trademarks are the outcome of establishing distinguishable names, signs and symbols for goods and services. Companies launching innovations, associate it to a new brand and apply for a new trademark to foster the perception by consumers (Millot, 2009) Since trademarks do not protect inventions as patents do but related with inventions being commercialised, the primary purpose of such protection can be thought as providing incentives for companies to invest in quality and reputation (Nam \& Barnett, 2011). 
Nearly all of the countries in the world register trademarks and protect them at the national level. Although one can use a trademark or service mark without registering it, it would be beneficial to register. That is because, if someone else tries to use your trademark or a trademark similar to yours, the registration of your trademark will protect you against problems. By the registration of a mark, a firm aims at making a name visible in the marketplace, and it protects the name against its use by competitors (Schmoch, 2003).

A service mark is used in connection with services. We can say that a service mark is similar to a trademark and differing only in that while the latter protects goods, service marks protect the services. Generally speaking, the term trademarks includes both trademark and service marks. The number of service mark applications has increased all over the world. The main reason is the growing awareness of marks as instruments of protection and thus an increased propensity to trademark registration (Schmoch, 2003). The service marks to distinguish the services of a company from the services of another company. Service marks are usually slogans (catchwords). Service marks may sometimes be confusing since they may encompass several product services groups. Nice International Classification System makes a trademark easy to recognise, categorise, and register among all signatory countries. That system helps business to identify the nature of the related good or service. 45 Nice classes aim to cover all economic activities: 34 Nice classes cover goods, while Nice classes 35-45 cover services. The division is based on the businesses that provide the services. These classifications exist so that companies registering a trademark can identify the nature of the related good or service and seek adequate intellectual property protection. Service marks are proven to be suitable to construct innovation indicators, as they meet essential preconditions, in particular correlation to innovation, good data access by electronic databases, and the possibility of operationalising them in relevant dimensions of disaggregation (Schmoch, 2003).

The relationship between trademarks and services has been drawing intense attraction in recent years. Schmoch (2003) has investigated the potential of marks, especially as an indication of innovation in the service sector. According to Schmoch, the analysis of the service sector is complicated as suitable statistical data is not available. He has notified that trademarks are applied to services as much as products contrary to patents, and therefore they had opened up the service field. Moreover, trademark data, provide several numbers of trademark applications that enable to obtain significantly meaningful statistical results and users can access these data via electronic databases, the data is sorted according to sectors, and finally, it has been emphasised that comparison can be made using an international database which is OHIM (Schmoch, 2003). Together with this, Schmoch (2003) has investigated if marks are truly related to the innovations in the service sector, and he has decided with this research that commercial innovations meet all of the prerequisites to establish an indication for service innovations. Additionally, he has noted that to interpret international level indicators depending on trademark applications, national and regional legal systems need to be particularly taken into consideration. Consequently, to be aware of the trademark application structures between offices, more research needs to be carried out. Although the literature on trademarks is limited, it has been increasing especially in Europe, in recent years. Sandner (2009), has looked into how the patent and trademark portfolios affected the market values of European markets.

Greenhalgh et. al., (2011) have indicated that there is a positive relationship between the trademark registration activities in the UK and efficiency, employment, wages, and increase in growth rate and performance. Various empirical studies have been carried out regarding the Relationship between marks and innovative activities, and particularly regarding service and high technology sectors. (Schmoch, 2003; Mendonca et al., 2004). Accordingly, Gotsch and Hipp (2012) have uncovered the beneficial indications of innovation in knowledge-intensive industries based on German questionnaire data, and Schmoch and Gauch (2009) have presented the advantages and limitations of using trademarks to measure novelty in service sectors in general. Besides these, Somaya and Graham (2006) have shown complementariness between the usage of trademarks, and copyright for USA trademark software in the 1990s, using both trademark lawsuits and registration data.

\section{The Effects of COVID-19 Pandemic on Service Sector Branding Tendency}

The main reasons for the differences in factors affected during the pandemic are due to the differences between the cultural structures of countries and the sector branches to which the country economies are based on and supported. The national cultural values and the culture of businesses affect the risk-taking, 
evolving, and global branding strategies of businesses (Melnyk et al., 2014). Each country has been affected differently from this process. The aspect affected most by the coronavirus pandemic equally in countries is consumer expenditures that support $70 \%$ of the economies. Economies are being affected negatively as people abstain from going to shops, restaurants, cinemas/theatres, offices, and other places that are open to the public. Although we talk about the aspects being affected being common in general, the themes that each country has been affected by most are different. The "Effects of COVID-19 Pandemic on Different Categories in Turkey Report" prepared by Deloitte Consulting (2020) has set forth the sectors that maximally affect the lifestyles in Turkey. According to the report, it has been noted that severe changes were seen in the lifestyles, business operations, and consumer habits of people. While remote education and home office working increased by 15 times, sectors such as airways, hotels and accommodations were affected negatively. The remote video conference and education systems such as Skype, Zoom and EBA have grown 15 times due to the shift of education and work to homes following the precautions taken to stop the spreading of the virus and therefore remote video conference and education has stood out against other categories. The fastest development in this category was the progress shown by the Education Information Network (EBA), which is the remote education system of the Ministry of Education.

As a result of online shopping which is another necessity of living indoors remote food and nutrition purchases have shown a rapid increase. National markets in this category have shown nearly two times more interaction in comparison to discount markets, due to their digitalisation investments, reliable logistics, and distribution infrastructures and e-commerce experien- ce. During this time where healthy eating and keeping the immunity strong is crucial, the consumers have steered towards vitamins, honey, and herbal products. As a result, the health products category has become one of the categories that were on the rise. Hobby sites such as knitting and handcrafts have also drawn interest from consumers who spent more time at home. These categories that had a rapid upward trend were followed by the internet-TV, media, pets, games, and clothes-shoes categories. The clothes-shoes category that started decreasing in the second week after the agenda of the outbreak has shown an upward trend in the last two weeks by aggressive discount campaigns; however, this increase in purchases may be temporary as social interaction is limited. Companies who adapted to e-commerce earlier on were affected less from the outbreak process. Companies who adapted rapidly to this process became successful. When the situation during the outbreak and prior the outbreak is evaluated, besides the companies that invested for solving the problems of the issues that were experienced in business processes during normal times, companies that rapidly adapted to changing expectations and demands during the process of the outbreak have also overcome these problems. It can be said that companies that have provided corporate services and product sales have become successful by turning towards consumer products and services, during this time when the working from home increased, and commerce slowed down. On the other hand, companies that have faced business loss and decrease in demand are organising free content and webinars to regain and maintain their connections with their consumers. In the table below, the service sector headings most affected according to the Deloitte report were grouped.

Table 1: Most Affected Service Sector Headings in Turkey

\begin{tabular}{|c|c|c|}
\hline Group Number & Categories & Service Sectors \\
\hline \multirow{4}{*}{1} & \multirow{4}{*}{$\begin{array}{l}\text { Most positively affected categories (Categories that showed } \\
\text { more than } 50 \% \text { interaction) }\end{array}$} & Remote education and business \\
\hline & & Healthcare products \\
\hline & & National market chains \\
\hline & & Hobby \\
\hline \multirow{6}{*}{2} & \multirow{6}{*}{$\begin{array}{l}\text { Highly positively affected categories (Categories showing } 30 \text { - } \\
50 \% \text { interaction increase) }\end{array}$} & Internet TV \\
\hline & & Kids/baby products \\
\hline & & Clothes-Shoes \\
\hline & & Media \\
\hline & & Pets \\
\hline & & Games \\
\hline
\end{tabular}


Table 1 (Continued): Most Affected Service Sector Headings in Turkey

\begin{tabular}{|c|c|c|}
\hline Group Number & Categories & Service Sectors \\
\hline \multirow{5}{*}{3} & \multirow{5}{*}{$\begin{array}{l}\text { Positively affected categories (Categories showing 10-30\% } \\
\text { interaction increase) }\end{array}$} & Personal care and cosmetics \\
\hline & & Undergarments \\
\hline & & Books \\
\hline & & Discount markets \\
\hline & & Fuel \\
\hline \multirow{3}{*}{4} & \multirow{3}{*}{$\begin{array}{l}\text { Categories that were affected at a low ratio (categories that } \\
\text { showed } 0-10 \% \text { interaction increase) }\end{array}$} & Home appliances/Building materials \\
\hline & & Social media Platforms \\
\hline & & Electronics \\
\hline \multirow{3}{*}{5} & \multirow{3}{*}{$\begin{array}{l}\text { Lowest negatively affected category (Categories showing } \\
\text { interaction loss between 0-10\%) }\end{array}$} & Banking services \\
\hline & & Educational Institutions \\
\hline & & Courier Companies \\
\hline \multirow{4}{*}{6} & \multirow{4}{*}{$\begin{array}{l}\text { Negatively affected categories (Categories that faced } 10-20 \% \\
\text { interaction loss) }\end{array}$} & Market places \\
\hline & & Public Sector \\
\hline & & Furniture \\
\hline & & Sports \\
\hline \multirow{8}{*}{7} & \multirow{8}{*}{$\begin{array}{l}\text { Highly negatively affected categories (Categories that faced } \\
30-50 \% \text { interaction loss) }\end{array}$} & Real estate \\
\hline & & Automobiles \\
\hline & & International marketplaces \\
\hline & & Take-away \\
\hline & & Sexual Health \\
\hline & & Airways \\
\hline & & Career \\
\hline & & $\begin{array}{l}\text { E-commerce consultancy/services and } \\
\text { digital payment systems }\end{array}$ \\
\hline
\end{tabular}

Source: Deloitte Consulting (2020). Effects of COVID-19 Pandemic on Different Categories in Turkey Report.

It has been noted that the sector headings presented in Table 1, were prepared during this period where the effects of the outbreak were initially felt. Therefore, data may show differences during the progression, stagnation of the outbreak or with new data or situations such as public intervention (Deloitte, 2020). It can be seen that the service sector received the hardest blow, and it will continue to do so. An indication relating to the situation of the service marks during this period has not been presented as yet, and we have not come across any study in the literature regarding this issue.

\section{Material and Methods}

\section{Research Methodology}

Different methods are used for service innovations and analysis thereof. Gotsch and Hipp (2012) have emphasised that trademark data sets can be used as innovation indicators. Mangani (2006) has stated that empirical studies analysing trademark data were not available until a few years ago. The research of Alleg- rezza and Guards-Rauch (1999) has tried to set forth the determinants of trademark applications. Studies based on trademark indicators have generally used the trademark data (as an independent variable) to collect information on the market value of companies and their innovation abilities.

Moreover, national offices have not paid much attention to collecting such data due to technological opportunities. However, we now have the standard analytic techniques and technology infrastructure to collect and analyse present information. On the other hand, when compared with patents, it is believed that marks deserve less empirical attention. The reason for this is that patents, contrary to trademarks, are much more related to technological advances and therefore to economic growth. Another possible reason is the thought that a trademark provides at least potentially less unearned income to the owner in comparison to a patent, as mentioned by Greenhut (1957). It is our main aim to emphasise the importance of service 
marks to country economies in terms of Turkish service mark applications. While making this emphasis, we have taken into consideration both the positive and the adverse effects of the pandemic process we are experiencing. Another one of our aims is to point out significant and meaningful findings by analyzing data sets that are mostly being disregarded in literature. We believe that conducting research using service mark data sets will contribute significantly to literature.

\section{Data Coverage}

To answer the research questions, we have got all service trademark application datasets in the database of the Turkish Patent and Trademark Office between January 2016 and June 2020. This research-based on comparison according to years has been carried out by taking the first six-month trademark application information for the year 2020 as the basis to determine the COVID-19 outbreak effects. In order to determine the change in recent years, we need to know the situation in previous years. Due to this reason, the service mark application data belonging to the first six months of the past five years have been included in this research. The trademark statistics for the research have been obtained from the official statistics page of the Turkish Patent and Trademark Office, and the Trademark application information has been collected from the trademark bulletins that are regularly published. Trademark bulletins are platforms where trademark applications are made available to the public; while marks are being registered, following application, it is decided if the said trademark applications should be published in the Official Marks Bulletin as a result of the figurative and legal examination that shall be conducted by the Turkish Patent and Trademark Office.

In this study, the text mining method has been used. In recent years the importance given to studies conducted through text mining using datasets has increased (Melnyk et al., 2014). As text mining methods do not generate results whose content is meaningful on its own, expressions, where complex structures are available, can be meaningfully classified using natural language processing techniques and various programs in combination with each other. For text importation, national language processing algorithms, and text data visualisation $\mathrm{KH}$ Coder text mining software is used (see. Higuchi, 2013). To determine the differences and rate of change between years, and SPSS 22.00 Statistics Program has been used. The trademark application data belonging to each year has been listed using an Excel program. An analysis is carried out by importing excel files using a $\mathrm{KH}$ Coder text mining software and converting them to text (.txt) format. Most of the signs in the trademark application cluster comprise some texts, and we have determined that standard character drawings are the most prevalent drawing type. Our data shows that most of the annual registrations are continuously provided for standard characters, and it reflects the probable reaction of application owners against more flexibility and potentially more extensive protection provided by the registration of these types of signs in comparison to other forms (Graham, Hancock, Marco and Myers, 2013). Product and service names, company trademark names in trademark applications are defined as trademarks that comprise a few words or a shorter text. In this study in order to limit a large amount of data, analysis has been carried out only on texts or words. Wordmarks comprise the product names and slogans that are used for the service sector.

\section{Research Process and Model}

To compile a comprehensive sample of new trademarks, we first download official trademarks bulletins from the TURKPATENT's website all trademark applications filed between January 1, 2016, and June $2020^{3}$. The year 2016 has been taken as the base year as the highest number of trademark applications has been carried out this year (Table 2). The determination of the year that is most productive and successful in studies to determine change and trends according to years makes it easier to interpret change rates and understand the present situation. We include year fixed effects in our main tests to adjust for this time trend. The changes and trends can be more clearly observed according to 2016 data, especially when compared with years following 2016 and particularly the time (from December 2019 until today, but in the study it has been limited to the end of 2020 June) where COVID-19 pandemic was experienced. Trademark applications are divided into two categories as product marks or service marks, according to their aims. As has been disclosed before, goods and services that are grouped fewer than 45 classes are available for trademark applications. The classes between 35 and 45 encompass service providing activities that are accepted as service marks.

In order to determine research themes, first of all, the listing of the most affected service sectors in Turkey during the COVID-19 pandemic have been grouped

\footnotetext{
${ }^{3}$ The trademark bulletins retrieved from: https://bulten.turkpatent.gov.tr/bulten/bulletinList/
} 
under service classes according to the data of Deloitte Consulting (2020) (Table 1). At the same time, the research themes have been verified by two trademark experts that are specialised in the field of trademark classing. Following this, an expression and terminology list belonging to the sectors that are most affected during the outbreak has been prepared concerning the service classes (Table 3). After this, co-occurrence, term extract, term frequency, and clustering analysis has been carried out on the service mark application list that belongs to the first six months of each year, using the $\mathrm{KH}$ Coder text mining software. The frequency of each research term was counted through the $\mathrm{KH}$ Coder text mining program, and the relationships between tagged parses were calculated using the Jaccard indices. The Jaccard index is calculated as shown in equation (1), where J, $\mathrm{x}$, and y represent the decompositions of the respective subjects. J indicates the degree to which words appear together.

$$
J(x, y)=|x \cap y| / x \mathrm{U} y \mid
$$

Cluster analysis is also a popular technique that uses data analysis algorithms. Clustering in a text mining context helps to better understand themes, concepts or events by dividing a collection of documents into groups based on the presence of similar themes (Goutam, Murali \& Statish, 2013). The change rate of the expression and terminology for each year has been calculated in comparison with the year 2016, which is the base year. Although a COVID-19 pandemic was experienced, it was seen that the number of trademark applications within the first six months of 2020 did not differ when compared with other years. Therefore, the change and trend of the trademark names in 2020 can be searched as sector-based and terminology belonging to affected sectors. The change rates of the determined terminology and the change rates of the terminology belonging to the year 2020 can be seen as a result of the impact study. The terms that are related with service mark classification of data clusters that have emerged due to the text mining method, and that are commonly used with sectors that are most affected by the pandemic and that we have heard the most of, during the pandemic, have been listed in Table 2 as research terms.

Table 2: The International Nice Classes of Service Marks and Terms of the Research with the impact of COVID-19

\begin{tabular}{|c|c|c|}
\hline $\begin{array}{l}\text { Nice } \\
\text { Class }\end{array}$ & Nice Class Headings & Research Terms \\
\hline 35 & $\begin{array}{l}\text { Advertising; business management; business } \\
\text { administration; office functions }\end{array}$ & $\begin{array}{l}\text { Personel, personnel recruitment, personnel placement, } \\
\text { employment agencies, career, unemployment, } \\
\text { employer, employee, business, e-marketing, digital } \\
\text { marketing, e-trading }\end{array}$ \\
\hline 36 & $\begin{array}{l}\text { Insurance services, financial and monetary affairs, real } \\
\text { estate brokers, real estate agencies and real estate } \\
\text { management, customs brokerage services, }\end{array}$ & $\begin{array}{l}\text { E-logistics, insurance, customs real estate, brokers, } \\
\text { money, finance }\end{array}$ \\
\hline 37 & $\begin{array}{l}\text { Construction Services; Installation and repair services; } \\
\text { Mining extraction, oil and gas drilling, Cleaning, care and } \\
\text { repair of clothing, Cleaning services for buildings (interior } \\
\text { and exterior), public areas, industrial premises; disinfecting, } \\
\text { vermin exterminating services, other than for agriculture, } \\
\text { rental of cleaning machines and equipment. }\end{array}$ & $\begin{array}{l}\text { Hygiene, cleaning, disinfection and disinfectant, } \\
\text { cologne, soap, virus repellent, mask, gloves, protective } \\
\text { clothing, apron, visor, social distance, home services, } \\
\text { cleaning services, spraying, construct, construction }\end{array}$ \\
\hline 38 & $\begin{array}{l}\text { Radio and television broadcasting services, } \\
\text { Telecommunication services; providing access to the } \\
\text { internet, News agencies }\end{array}$ & $\begin{array}{l}\text { Communication, internet, news agency, internet } \\
\text { services }\end{array}$ \\
\hline 39 & $\begin{array}{l}\text { Transport; Packaging and storage of goods; Travel } \\
\text { arrangement }\end{array}$ & $\begin{array}{l}\text { Courier, courier services, storage, storage services, } \\
\text { caravan, boat, tour arrangement, travel, transportation, } \\
\text { airlines }\end{array}$ \\
\hline 40 & $\begin{array}{l}\text { Treatment of materials; Recycling of waste and trash; Air } \\
\text { purification and treatment of water; Printing services; Food } \\
\text { and drink preservation }\end{array}$ & $\begin{array}{l}\text { Recycling, purification, hobby, sewing, knitting, } \\
\text { tailoring, woodwork, frame, assembly, decor, design, } \\
\text { pottery, food processing, food canning, energy supply, } \\
\text { generator supply services }\end{array}$ \\
\hline
\end{tabular}


Table 2 (Continued): The International Nice Classes of Service Marks and Terms of the Research with the impact of COVID-19

\begin{tabular}{|c|c|c|}
\hline $\begin{array}{l}\text { Nice } \\
\text { Class }\end{array}$ & Nice Class Headings & Research Terms \\
\hline 41 & $\begin{array}{l}\text { Education; Providing of training; Entertainment; Sporting } \\
\text { and cultural activities }\end{array}$ & $\begin{array}{l}\text { Education, school, college, university, academy, sport, } \\
\text { culture, visual meeting or education platforms (eba, } \\
\text { zoom, teams et al.), e-learning, distance learning, } \\
\text { e-classroom, e-conference, e-education, symposium, } \\
\text { congress, concert, cinema, theatre, museum, } \\
\text { entertainment }\end{array}$ \\
\hline 42 & $\begin{array}{l}\text { Scientific and technological services and research and } \\
\text { design relating thereto; Industrial analysis, industrial } \\
\text { research and industrial design services; Quality control } \\
\text { and authentication services; Design and development of } \\
\text { computer hardware and software }\end{array}$ & $\begin{array}{l}\text { Web design, hosting, domain, quality and standard } \\
\text { certification, hardware, software, research }\end{array}$ \\
\hline 43 & $\begin{array}{l}\text { Services for providing food and drink; Temporary } \\
\text { accommodation, Day-nurseries (crèches), Boarding for } \\
\text { animals }\end{array}$ & $\begin{array}{l}\text { Tourism, hotel, motel, hostel, residence, reservation, } \\
\text { meeting, restaurant, bar, cafe }\end{array}$ \\
\hline 44 & $\begin{array}{l}\text { Medical services; veterinary services; hygienic and beauty } \\
\text { care for human beings or animals; agriculture, aquaculture, } \\
\text { horticulture and forestry services }\end{array}$ & $\begin{array}{l}\text { Doctor, health, treatment, medical, quarantine, } \\
\text { hospital, clinic, medicine, nurse, nursing, caring, } \\
\text { health counselling, pandemic, beauty, beauty centres, } \\
\text { cosmetics, hairdressing, make up, aesthetic }\end{array}$ \\
\hline 45 & $\begin{array}{l}\text { Legal services; security services for the physical protection } \\
\text { of tangible property and individuals; personal and } \\
\text { social services rendered by others to meet the needs of } \\
\text { individuals. }\end{array}$ & Marriage, weddings, funeral services, security \\
\hline
\end{tabular}

In Table 2, the terms that are related to the sectors that are most affected by the pandemic have been listed according to the service headings in the international Nice trademark classification system. These expressions are important in finding the branding trends during the pandemic, and the service groups that were most affected and changed. The research design is presented in figure 1 to clearly show the research methodology step by step.

\section{Analysis and Findings}

The service mark applications, according to years, have been shown in Table 3. The number of service mark applications in the first six months of 2020 has been extracted from the trademark bulletins for research, and it has been noted that the number of applications was 42000 . The official data statistics are published based on years. Due to this reason, the official information of the year 2020 is as much as the information that is obtained from trademark bulletins. The general information does not comprise trademark information belonging to personal names and information. Due to this reason, carrying out analysis using general terms and sector headings is ethical and important for us, both for providing data confidentiality and trademark privacy.

It can be seen in Table 1 that the highest number of service mark applications were carried out in the year 2016. The service mark applications need to be examined as of the year 2016 in order to determine qualitative change and trends in trademark applications under the 2020 pandemic conditions. Service-mark applications similar to commercial product applications are on the rise in Turkey too as in countries all around the world. The analysis has been started by changing the Turkish characters into English characters as the Turkish language was not recognised in the program. On the contrary, it would have been impossible to upload the datasets into the program. The exceptional characters in the dataset would have made the operation of the program difficult. As the letters " $ı, u, \ddot{u}, \ddot{u}, s ̧, c ̧, \mathrm{~g}^{\prime}$ used in Turkish will not change the meaning of the terms, and they have been replaced with "i, u, o, s, c, g". Later on the characters or words such as "figure, .com, Itd, şti, a,s, \&, $\%$, \#, and, or, .tr, san, limited, country, city" were taken out of the data sets as it was believed that they were meaningless, and they did not change the originality of the trademark and that they could affect the general 
values as they were repetitive. The term frequency plots of the datasets were presented in Figure 1. According to the figure, there are differences between plots according to years. As the datasets are formed of many terms, this led to very high data loads. Due to this reason, it seems that it is almost impossible for us to be able to find meaning from these plots. Therefore, the analysis of each term would lead to better results in terms of the validity and reliability of the research.

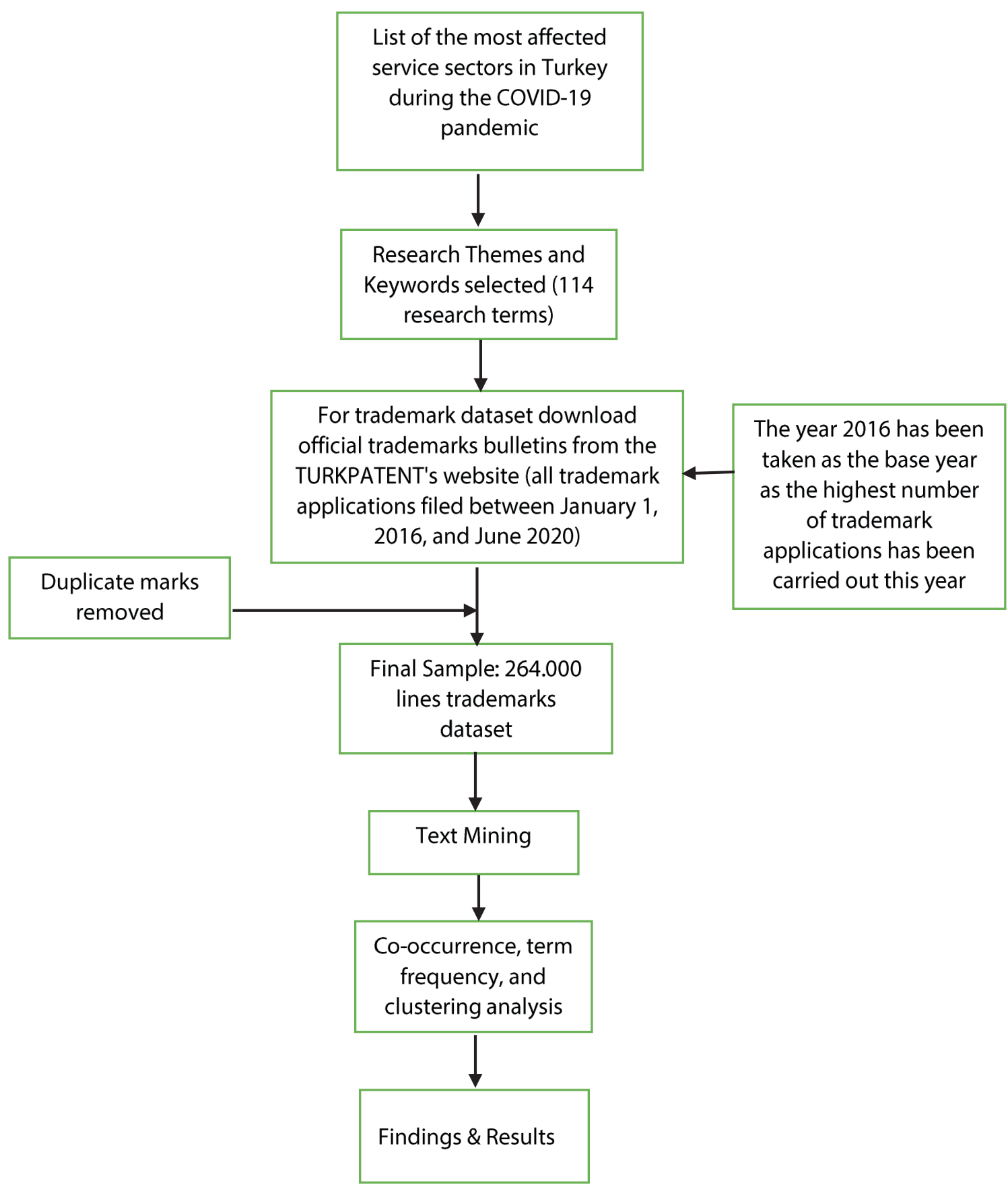

Figure 1: Research Flow-Diagram 
Table 3: Numbers of Service Mark Applications by Years

\begin{tabular}{lllllllll}
\hline Class Codes & $\mathbf{2 0 1 2}$ & $\mathbf{2 0 1 3}$ & $\mathbf{2 0 1 4}$ & $\mathbf{2 0 1 5}$ & $\mathbf{2 0 1 6}$ & $\mathbf{2 0 1 7}$ & $\mathbf{2 0 1 8}$ & $\mathbf{2 0 1 9}$ \\
\hline 35 & 14547 & 28147 & 26342 & 26155 & 32075 & 30851 & 33922 & 31911 \\
\hline 36 & 2426 & 3538 & 3681 & 3990 & 4813 & 4419 & 4428 & 3300 \\
\hline 37 & 4702 & 6046 & 6898 & 7276 & 8822 & 7989 & 7876 & 5309 \\
\hline 38 & 2524 & 3831 & 4262 & 3863 & 4120 & 3600 & 3198 & 2840 \\
\hline 39 & 2308 & 3003 & 3463 & 3466 & 4127 & 3531 & 3708 & 3404 \\
\hline 40 & 1877 & 2493 & 2942 & 2996 & 3206 & 2860 & 3111 & 2596 \\
\hline 41 & 5090 & 7128 & 8423 & 8497 & 10476 & 9882 & 10269 & 9110 \\
\hline 42 & 3310 & 4725 & 5661 & 5654 & 6688 & 6367 & 6861 & 6018 \\
\hline 43 & 4554 & 5942 & 7439 & 8242 & 10102 & 9601 & 10329 & 9631 \\
\hline 44 & 1475 & 1877 & 2310 & 2555 & 2911 & 2939 & 3138 & 3023 \\
\hline 45 & 725 & 909 & 1124 & 1398 & 1474 & 1368 & 1531 & 1603 \\
\hline Total & 43538 & 67639 & 72545 & 74092 & $\mathbf{8 8 8 1 4}$ & 83407 & 88371 & 78745 \\
\hline
\end{tabular}

Resource: https://www.turkpatent.gov.tr/TURKPATENT/statistics/
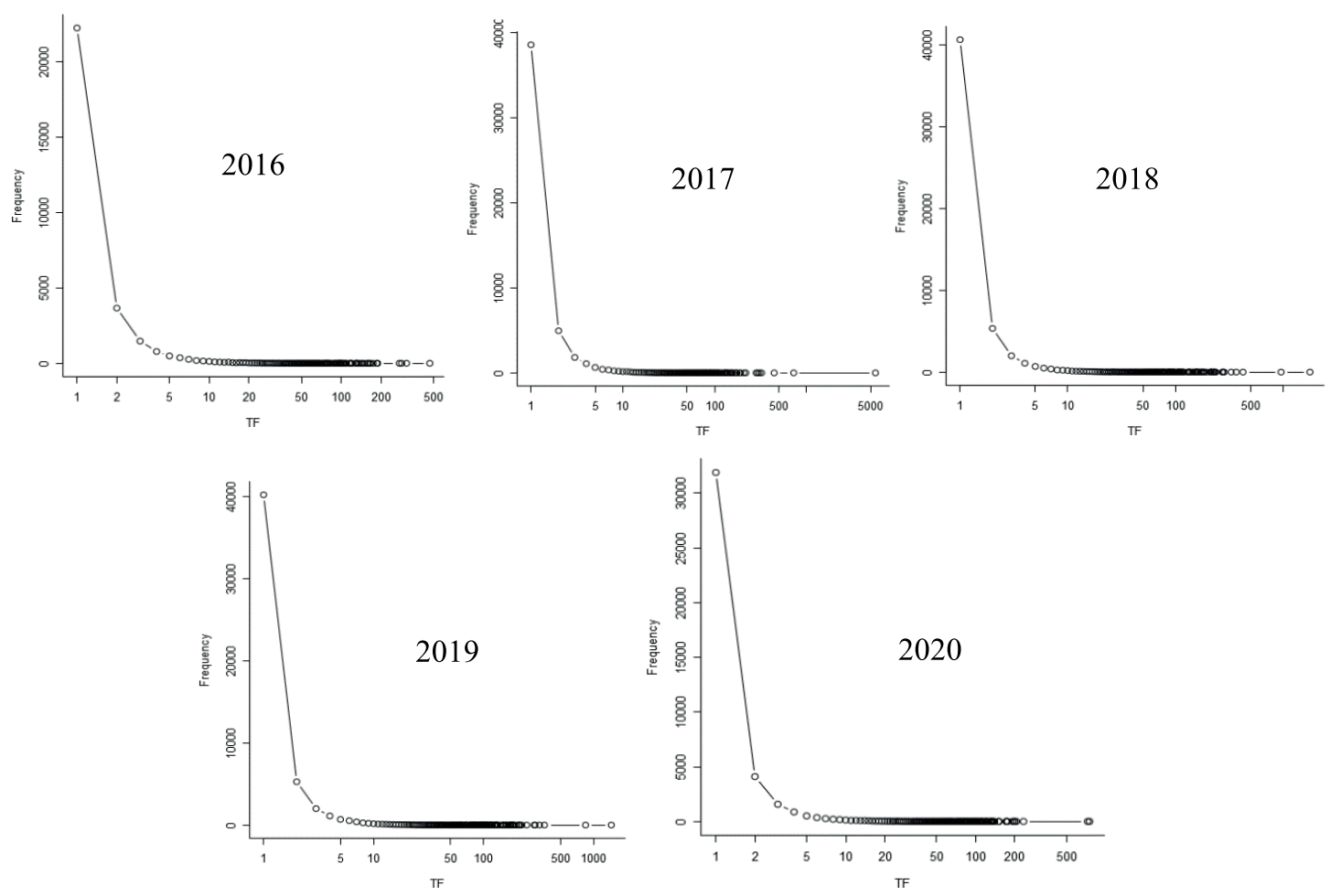

Figure 2: Term Frequency Plots by Years (2016-2020)

Figure 2 reflects the general distribution frequencies of the terms according to years. The points were frequency increased show great differences. The frequency distributions belonging to all terms in the datasets show the differences between years to us. Accordingly, we can say that the term frequency in the year 2020 accumulated differently in comparison to other years. We have presented the frequency and percentages belonging to the research terms in Table 4. Table 4 presents change rates derived from relative weights of frequencies within the annual totals. 


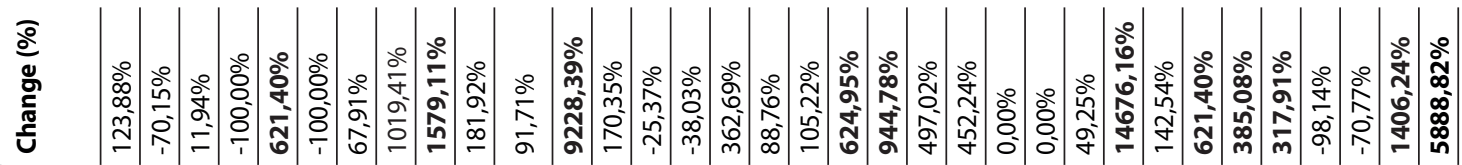

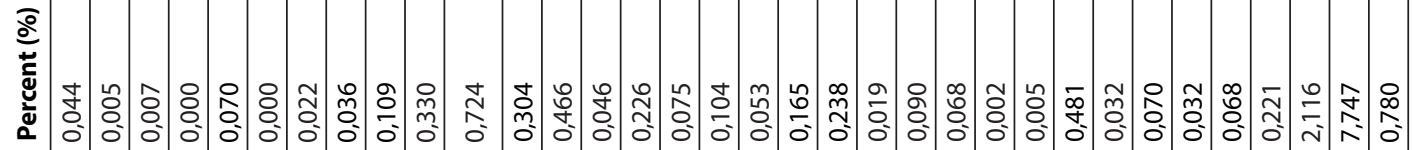

ลั่ 产

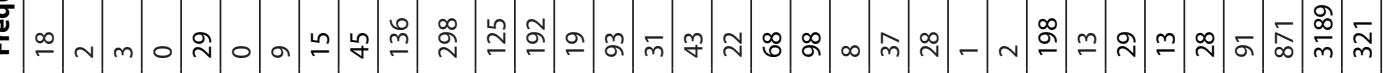

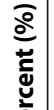
วัด

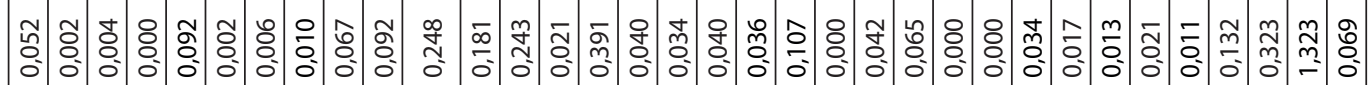

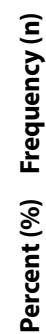

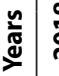

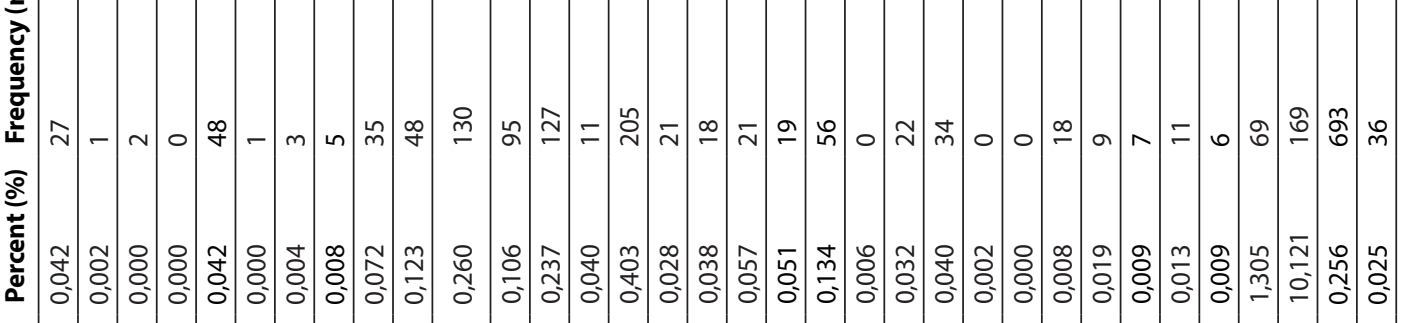

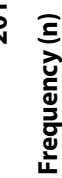

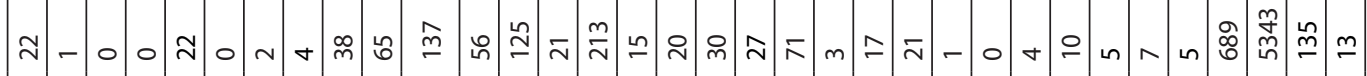
竞

ํํำ

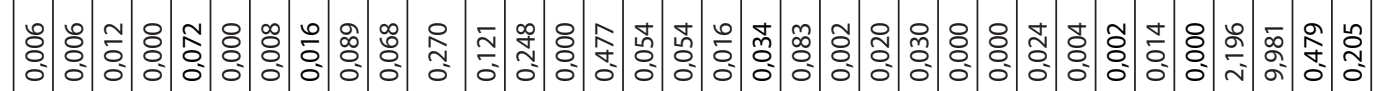

$\frac{\bar{c}}{\bar{c}}$

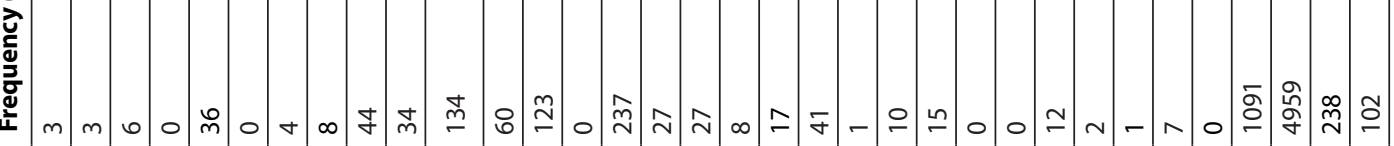

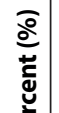

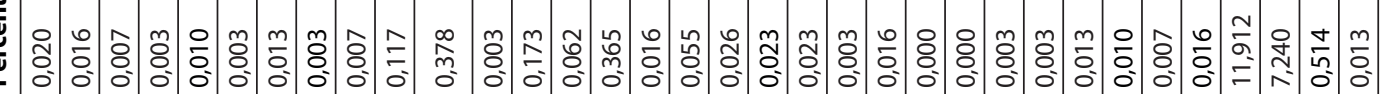

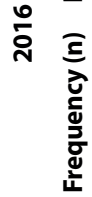

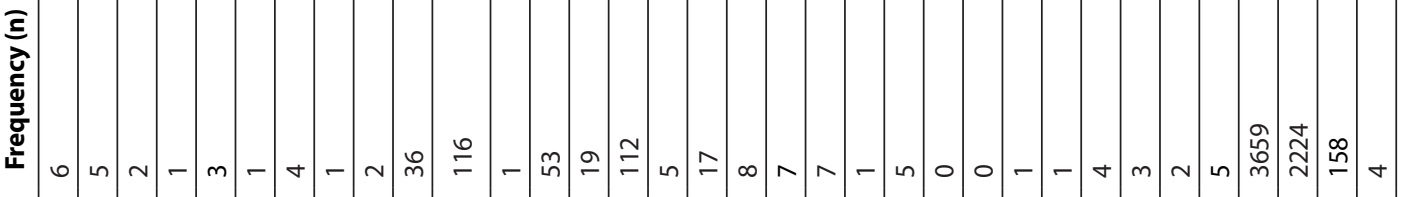

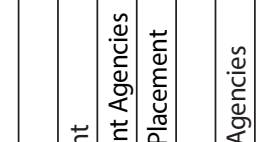

幽

旅

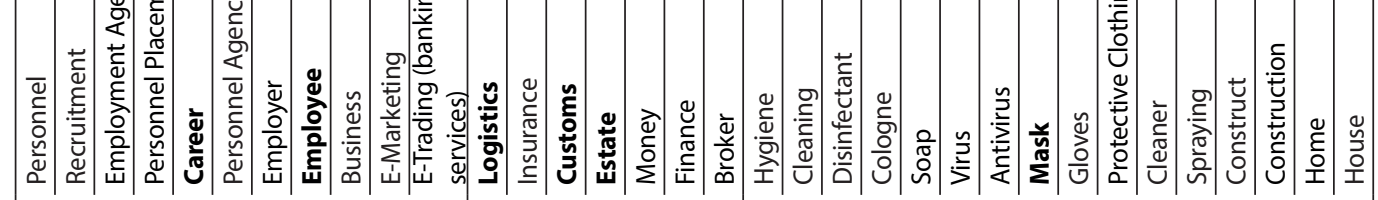

送愛

in

$\stackrel{\circ}{m}$

$\hat{m}$ 


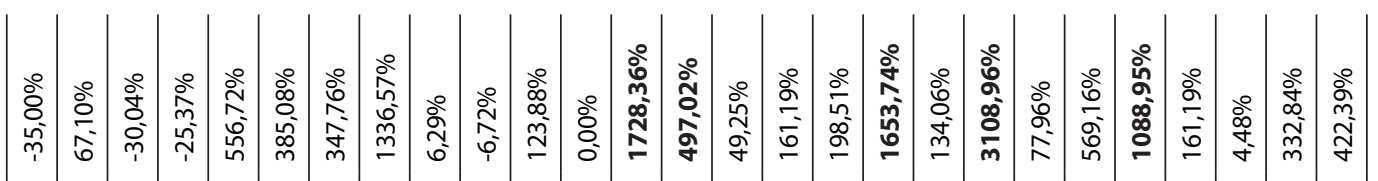

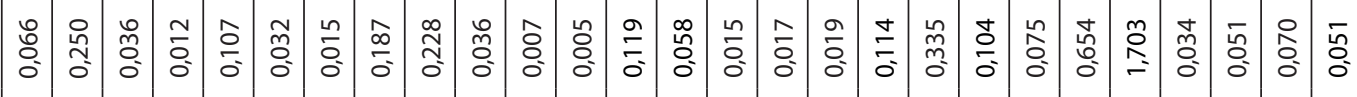

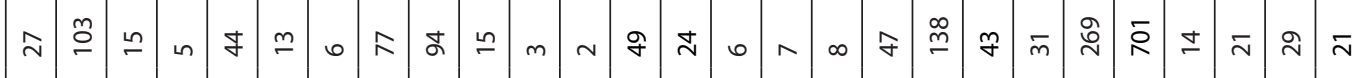

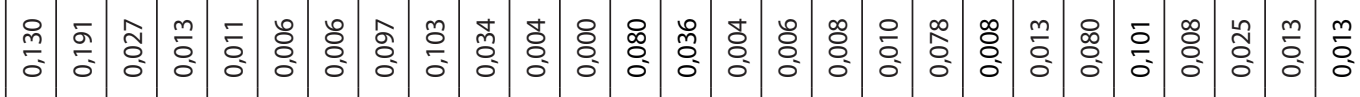

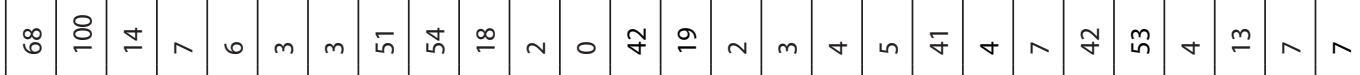

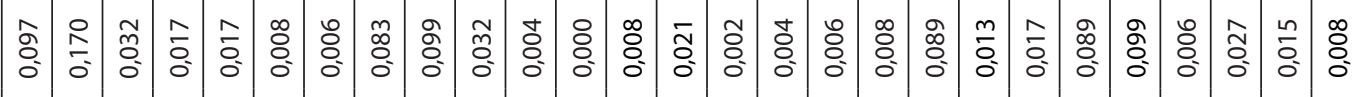

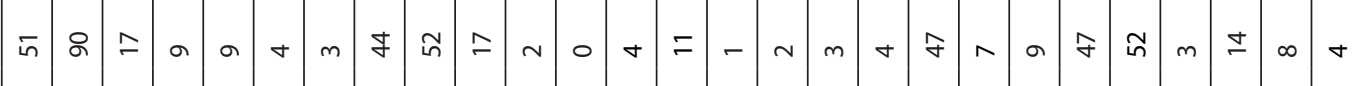

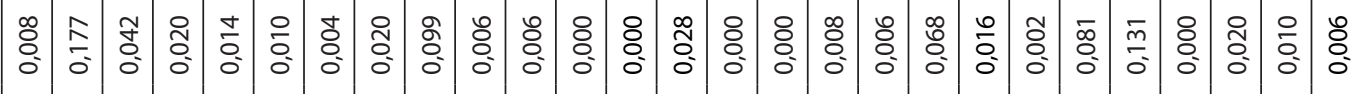

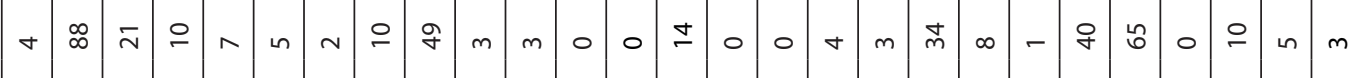

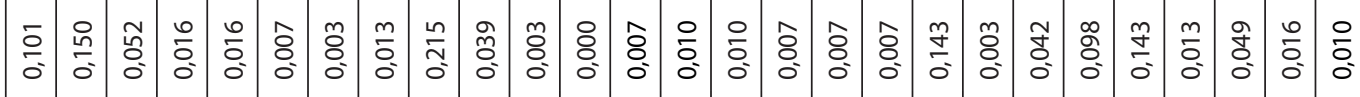

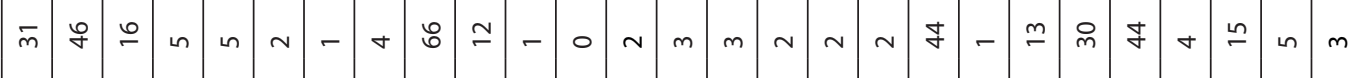

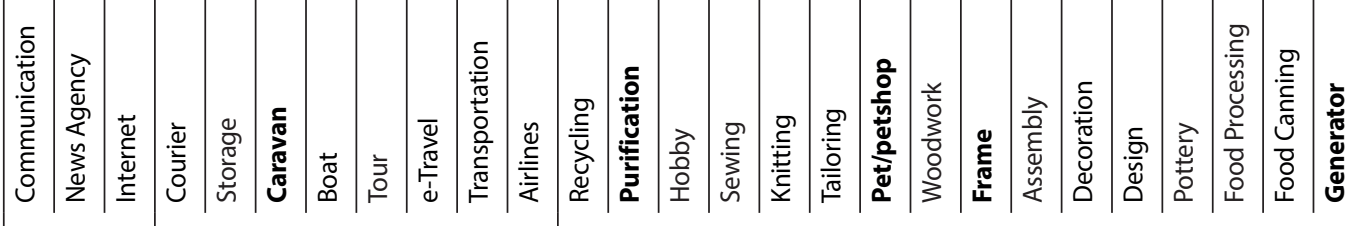

$\infty$

के

8 


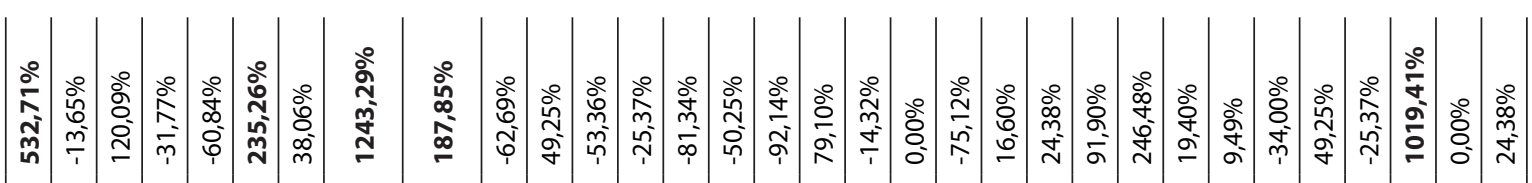

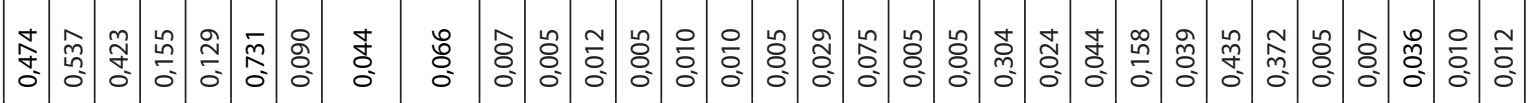

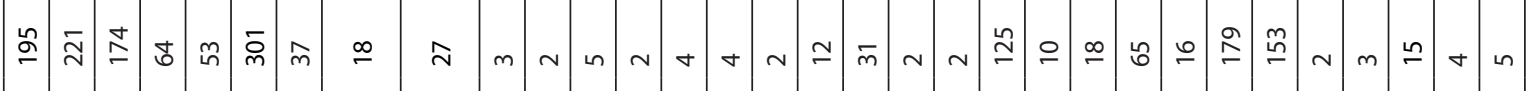

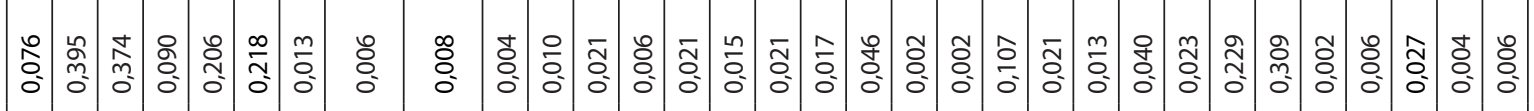

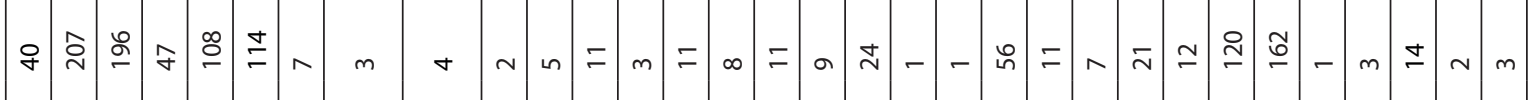

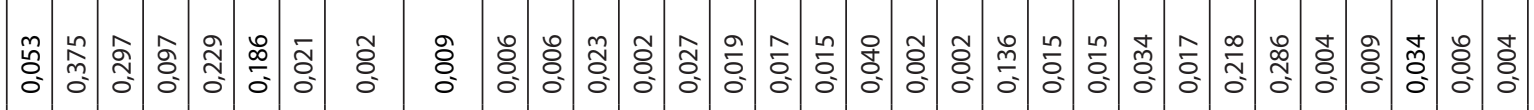

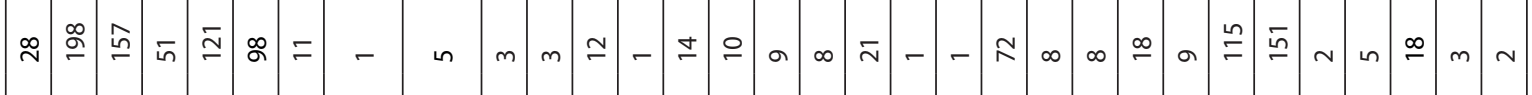

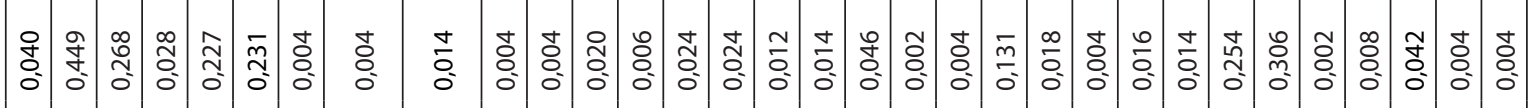

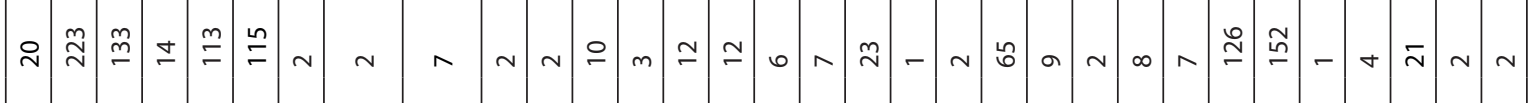

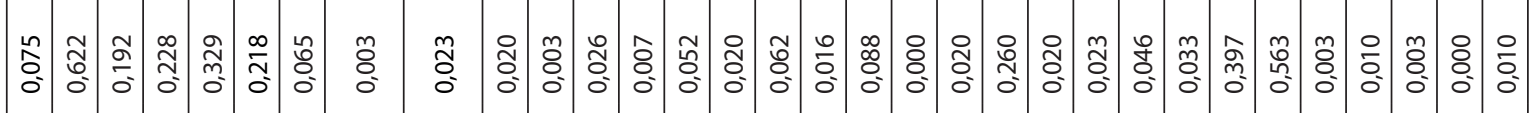
m

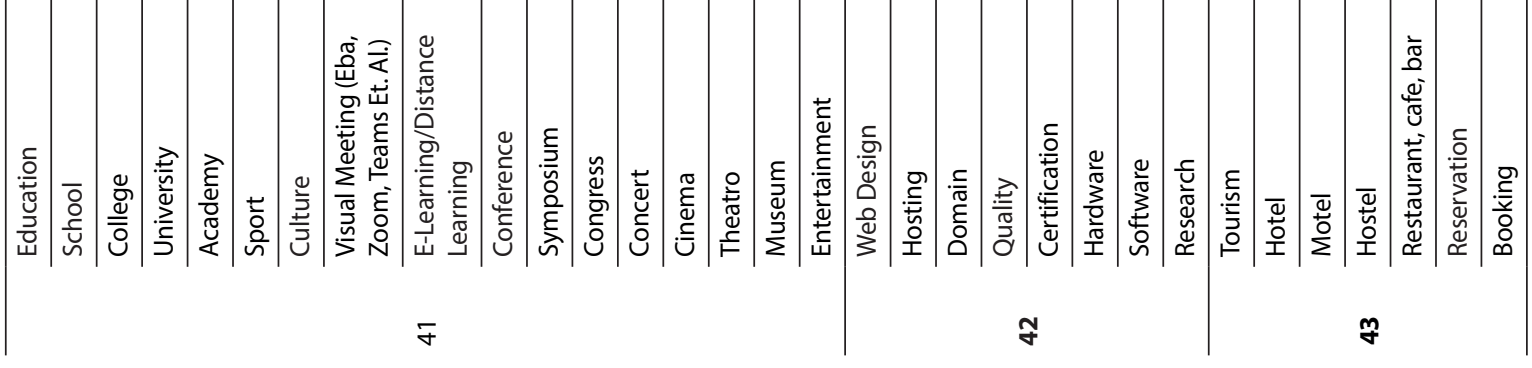

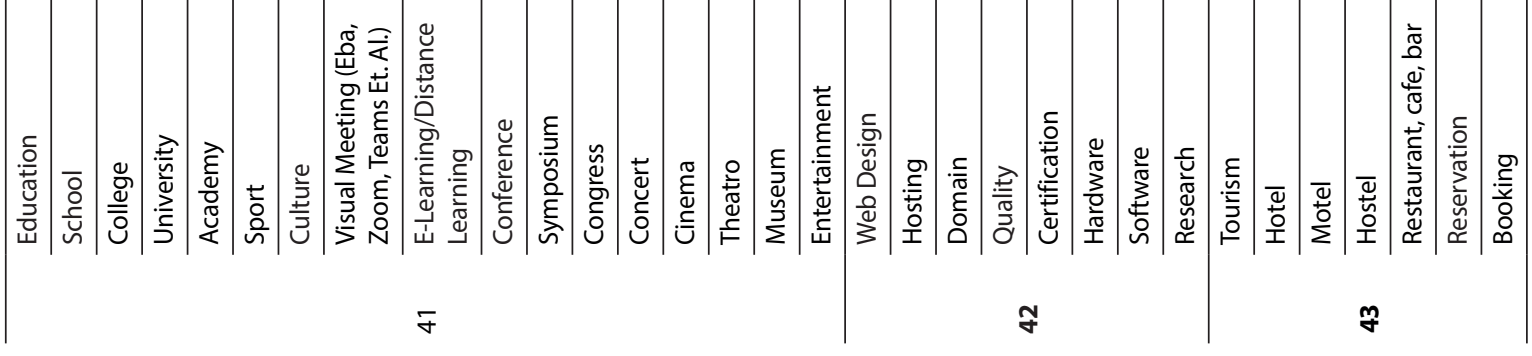




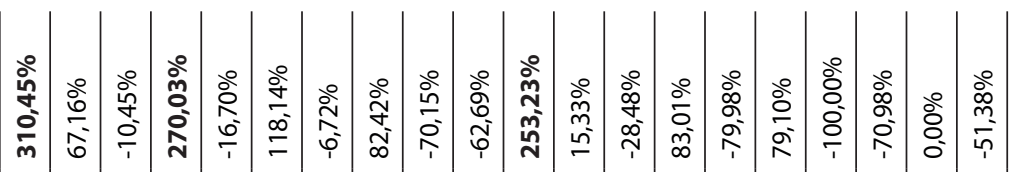

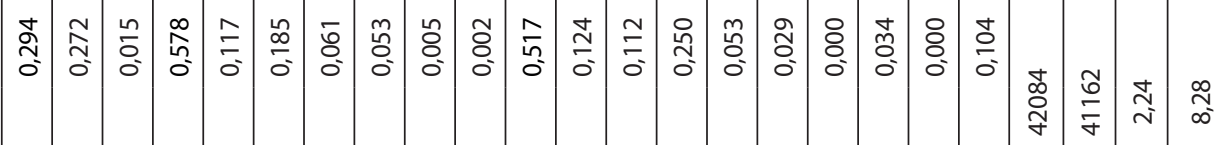

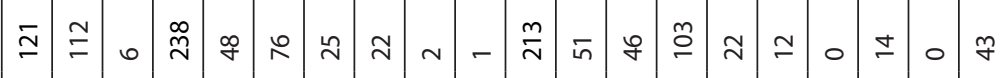

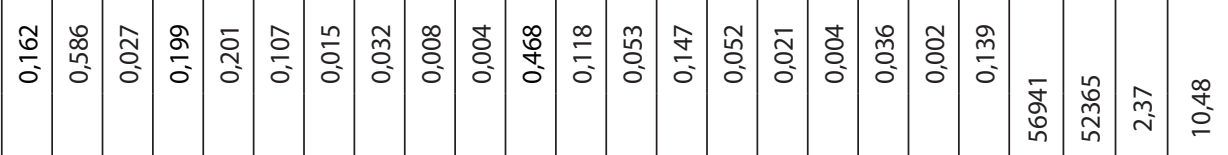

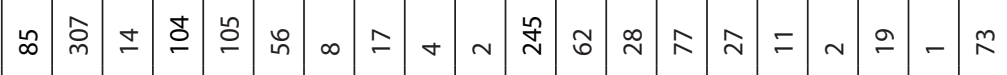

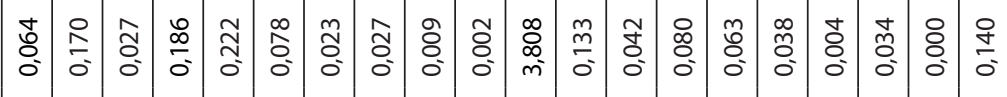

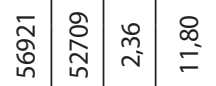

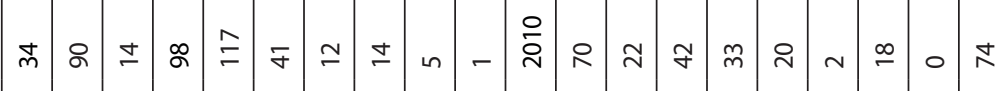

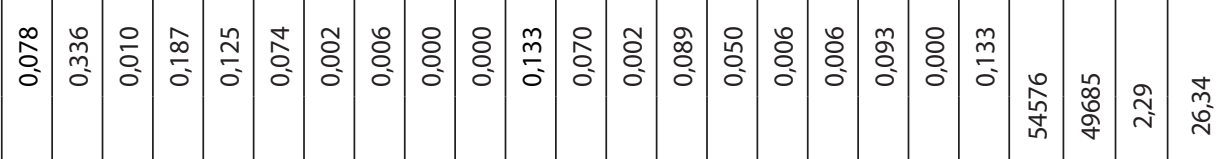

$$
\begin{aligned}
& \text { m) }
\end{aligned}
$$

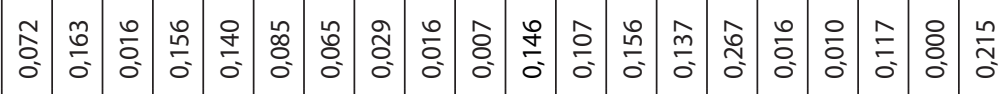

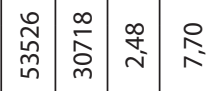

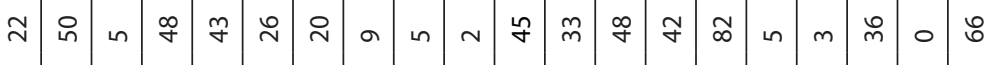

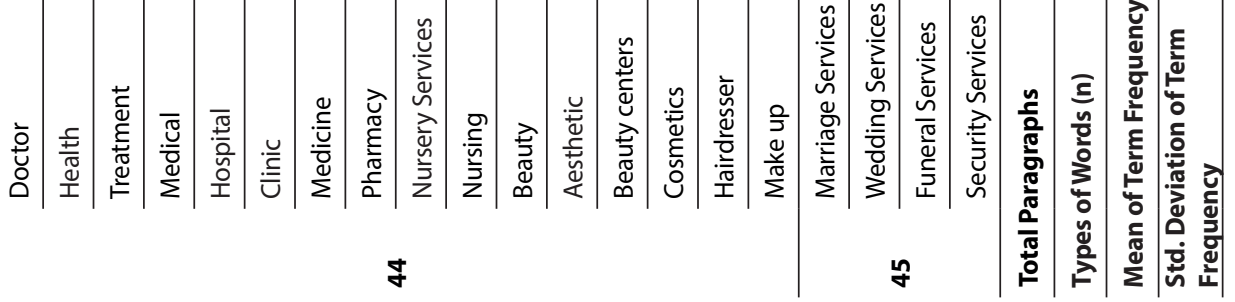


The dataset that is formed of a total of 264000 lines has been analysed using a text mining method using 114 research terms in total. In Table 4, we can see that there was a serious change in the subheadings, and that there was no change in some headings and that there was a negative trend in other headings, belonging to various sectors in the service mark applications by years. In Table 4, the service sector headings that positively changed for the most in trademark applications of class 35 were in the sectors that comprised the terms of career $(621,40 \%)$, employee $(1019,41 \%)$ and business $(1579,11 \%)$. It was noted that the highest positively changed term concerning class 36 was logistics $(9228,39 \%)$, and the terms, customs $(-25,37 \%)$ and real estate $(-38,03 \%)$ were changed negatively. The most positive increase in class 37 has been companies that marketed masks with a rate of $14676,16 \%$, wherein most of these companies were active in digital platforms. The trend for branding was positive in the terms hygiene (624,95\%), disinfectant $(497,02 \%)$, cologne $(452,24 \%)$, protective $(621,40 \%)$, disinfestations $(317,91 \%)$, cleaner $(385,08 \%)$ and gloves $(142,54 \%)$ that are included in class 37 and are focused on cleaning products. Many changes were observed in service mark names that included the terms home $(1406,24 \%)$ and house $(5888,82 \%)$. Another class that showed the most change was class 39 , related to transportation and travel marks, which included the terms warehouse $(556,72 \%)$, caravans $(385,08 \%)$, boats $(347,76 \%)$ and tours $(1336,57 \%)$. However, a negative trend was seen in trademark applications that included the terms courier $(-25,37 \%)$ and transportation $(-6,72 \%)$. A positive increase was observed in all terms related to class 40 . The most change was seen in terms related with businesses involving purification (1728,36\%) and generators (422,39\%) and hobby terms such as framing $(3108,96 \%)$, Pet/pet shop $(1653,74 \%)$, design (1088,95\%) and decoration (569,16\%). In terminology analysis related to education and cultural services regarding class 41 , the increase was observed in service applications with terms related to online education platforms (1243,29\%), digital education platform $(532,71 \%)$, and sports $(235,26 \%)$. In applications related to cultural activities, negative trend can be observed, such as (Conference $(-62,69 \%)$, Congress $(-53,36 \%)$, Concert $(-25,37 \%)$, Cinema $(-81,34 \%)$, Theatre $(-50,25 \%)$, Museum $(-92,14 \%))$. In the research terms related to engineering services, computers, software services, graphic arts design services included in class 42 , a generally fluctuating trend was observed (both positive and negative changes). The positive change comprises the expression related to software
(246,48\%). A negative trend was observed in terms related to terms searches regarding restaurant, bar, café services, and hotel services, included in class 43 , except the terms restaurant $(1019,41 \%)$. When we take a look at the trademark applications that encompass hospital services, medical services, and beauty care services included in class 44 , we can see that a significant change was not present, on the contrary, a negative trend was observed. We can talk about a very small amount of increase in the terms doctor $(310,45 \%)$ related to medical services and beauty $(253,23 \%)$ related to beauty care services. A negative trend was observed in terms related to legal services and security services regarding class 45 , (marriage services $(-100,00 \%)$, wedding services $(-70,98 \%)$, security services $(-51,38 \%))$.

\section{Results and Discussion}

In this article, where we aim to display the impact on branding trends, of the pandemic that has taken hold of the whole world, we can say that branding trends were not affected quantitatively even because of a serious condition such as a pandemic. When we take a look at the trademark application statistics during this time course, we can see that the number is nearly the same as in previous years. The reason for this can be reflected as trademark applications being important indicators for countries, and that many countries have given more and more importance systematically to branding processes, including Turkey. Marks have the potential to display certain types of dynamic abilities, related to obtaining the opportunity to penetrate new markets, especially for products and services. These abilities can be captured by the trademark applications in markets into which the companies have entered gradually. In this study, we selected 114 research terms to determine the innovations in the service sector in recent times, to obtain meaningful and valid evidence from an excessive number of textual data. These research terms comprehensively included the economic markets and the classification belonging to the service sector of which we are a part of. After scanning the enormous amount of datasets with $\mathrm{KH}$ Coder software that has been specially developed for text mining, we have made comparisons by years based on averages and frequencies. According to our study, we can see that the most intriguing branding trends during the pandemic can be seen in the services of providing masks and warehouse services that have increased significantly in comparison to other years. The headings that were most positively affected by the pandemic, according to the afore-mentioned Deloitte Consulting (2020) report, 
that matched with the results of our research were remote education, digital commerce, and hobby services. The service sectors that were positively affected at a lower rate in the report were pet shops, pet care, and pet necessities. Another result that is also in compliance with the report is the beauty, cosmetics, and self-care marks which are sectors that were positively affected. In the report, it has been mentioned that courier and cargo services were negatively affected and in our research, we have also observed that these marks had a negative change rate.

Besides these, sector headings that had an opposite branding trend have also been discovered. In the report, even though it has been stated that construction materials were positively affected in low ratio, it was observed that its reflection on branding showed a high increase. Although we discovered that there was a positive increase in the branding related to education services, we can see that education services are close to the top of the list of negatively affected sectors. Although the branding rate of services related to sports showed a positive increase, it is included among the sectors that are positively affected. Although trademark applications for career services showed a very high positive increase, in the sector report, it is included in the category that was most negatively affected. Another branding trend that is not compatible with the report is related to e-commerce services or consultancy services thereof. In our study, we have observed that electronic commerce services positively increased. Finally, it is noted that the applications during the time where the pandemic had gained ground were trending towards services such as digital platforms and virtual organisations.

\section{Research Limitations and Future Research}

In this research, as it is difficult to analyse the service sector, there are limitations. First of all, sufficient empirical research data is not available regarding commercial and service marks. The reason for this is that large amounts of data need to be sorted and turned into meaningful data, and this is time consuming and endeavouring process. As the first six months of the year, 2020 was researched to determine the effects of the pandemic process. We had to include the first six months of the previous years that we made the comparison to. The reason for this is that we wanted to reveal reliable and valid information showing the effects of the outbreak on the change of data numbers and branding trends. In the future, when data is obtained for the entire year, we believe that comparison for the whole year will result in more meaningful results and the usage of the data for the first six months only for every year can be expressed as the constraint of this study. The other constraint of this research can be the excessive numbers of textual data. The reason for this is that selecting and sorting data that is meaningful and useful from the excessive data necessitates technical infrastructure. It has taken a long time to pick out the useless and meaningless expressions from the dataset. It can be thought that some of the determined search expressions could be related to more than one class; however, as each expression encompasses different sectors, the resemblance among them has shown great differences. We had to be more cautious regarding the decrease and increase conditions, as the change rate of each research term was to be determined according to years. Due to this reason, the selection of the year where service mark applications were at a peak level as the base year, gave us results that could be scientifically described. In the studies to be carried out in the future, the focus could be given to the service sector innovations between countries. While comparisons are made according to countries, the performances of different service sectors in each country are compared, and focusing on international comparisons could bring out more generalisable results. Classification in terms of economic indicators can be carried out regarding the comparison of the service sector innovations between countries. 


\section{References}

Alan, H., \& Yeloğlu, H. O. (2013). Branding and Innovativeness, Siirt Üniversitesi, İktisadi Yenilik Dergisi, 1 (1), July: 13-26.

Allegrezza, S. A., \& Guard, R. (1999). The Determinants of Trademark Deposits: An Econometric Analysis (A Case Study of the BENELUX). Economique Appliqueé, 52 (2), 1-68.

Amara, N., Landry, R., \& Traoré, N. (2008). Managing the Protection of Innovations in Knowledge-Intensive Business Services. Research Policy, 37(9), 1530-1547. http://dx.doi. org/10.1016/j.respol.2008.07.001

Begg, I. (1993). The Service Sector in Regional Development. Regional Studies, 27(8), 817-825.

Birinci, Y. (2009). The Role of Effective Protection of IP Right on Economic Growth. In: Neslihan Aydoğan editors. Innovation Policies, Business Creation and Economic Development: A Comparative Approach (International Studies in Entrepreneurship) Springer: NewYork, 51-62.

Chaston, I. (2017). The Service Sector. Technological Entrepreneurship, London: Palgrave Macmillan

Deloitte Consulting, (2020). Effects of COVID-19 Pandemic on Different Categories in Turkey Report, Retrieved from https:// www2.deloitte.com/tr/tr/pages/consulting/articles/kuresel-covid-19-salgininin-turkiyede-farkli-kategorilere-etkileri.html

Deloitte Consulting, (2018). The services powerhouse: Increasingly vital to world economic growth Issues by the Numbers, Retrieved from https://www2.deloitte.com/us/en/ insights/economy/issues-by-the-numbers/trade-in-services-economy-growth.html

Den Hertog, P., \& Bilderbeek, R. (1999). Conceptualising service innovation and service innovation patterns, Thematic essay within the framework of the Research Programme Strategic Information Provision on Innovation and Services (SIID) for the Ministry of Economic Affairs, Directorate for General Technology Policy.

Durst, S., Mention, A.L., \& Poutanen, P. (2015). Service innovation and its impact: What do we know about?. Investigaciones Europeas de Dirección y Economía de La Empresa, $21(2), 65-72$.

Flikkema, M.J, De Man, A.P., \& Castaldi, C. (2014). Are Trademark Counts a Valid Indicator of Innovation? Results of an InDepth Study of New Benelux Trademarks Filed by SMEs, Industry and Innovation, 21(4), 310-331

Goutam, C., Murali, P. \& Statish, G. (2013). Text Mining Analysis, Practical Methods, Examples, and Case Studies using SAS, SAS Press.

Gopinath, G. (2020). Limiting the economic fallout of the coronavirus with large targeted policies. In: Mitigating the COVID Economic Crisis: Act Fast and Do Whatever It Takes, CEPR Press.
Gotsch, M., \& Hipp, C. (2012). Measurement of Innovation Activities in the Knowledge-Intensive Services Industry: A Trademark Approach. The Service Industries Journal, 32(13), 2167-2184. http://dx.doi.org/10.1080/02642069.2011.57 4275

Goetsch, M., \& Hipp, C. (2014). Using trademarks to measure innovation in knowledge-intensive business services. Technology Innovation Management Review, 4(5), 18-30. Retrieved from https://timreview.ca/article/790

Graham, S., Hancock, G., Marco, A., \& Myers, A., (2013). The USPTO trademark case files dataset: descriptions, lessons, and insights. Journal of Economics \& Management Strategy, 22,669-705.

Greenhalgh, C., Rogers, M., Schautcheck, P., \& Sena, V. (2011). Trademark Incentives, UK Intellectual Property Office.

Greenhut, M. L. (1957). Free entry and the trade mark-trade name protection, Southern Economic Journal, 12(2), 170-181.

Gryszkiewicz, L., Giannopoulou, E., \& Barlatier, P. J. (2013). Service innovation capabilities: what are they?. International Journal of Services, Economics and Management, 5(1/2), 125.

Higuchi, K. (2013). KH Coder. http://khc.sourceforge.net/en/

Huang, Y., Lin, C., Wang. P., \& Xu, Z. (2020). Saving China from the coronavirus and economic meltdown: Experiences and lessons. In: Mitigating the COVID Economic Crisis: Act Fast and Do Whatever It Takes, CEPR Press.

Mangàni, A. (2006). An economic analysis of rise of service marks. Journal of Intellectual Property Right (LIPR), 11(4), 249-259

Melnyk, V., Giarratana, M., \& Torres, A. (2014). Marking your trade: Cultural factors in the prolongation of trademarks. Journal of Business Research, 67(4), 478-485.

Mendonça, S., Pereira, T. S., \& Godinho, M. M. (2004). Trademarks as an Indicator of Innovation and Industrial Change. Research Policy, 33(9), 1385-1404. http://dx.doi. org/10.1016/j.respol.2004.09.005

Millot, V. (2009). Trademarks as an indicator of product and marketing innovations. Paris: OECD Science, Technology and Industry Working Papers, 2009/6.

Ostrom, A. L., Bitner, M. J., Brown, S. W., Burkhard, K. A., Goul, M., Smith-Daniels, V., Demirkan, H., \& Rabinovich, E. (2010). Moving forward and making a difference: Research priorities for the science of service. Journal of Service Research, $13(1), 4-36$.

Ramelli S, Wagner A. (2020). What the stock market tells us about the consequences of COVID-19. In: Mitigating the COVID Economic Crisis: Act Fast and Do Whatever It Takes CEPR Press

Sandner, P.G. (2009). The Valuation of Intangible Assets: An Exploration of Patent and Trademark Portfolios, Wiesbaden, Germany: Gabler. 
Schmoch, U. (2003). Service marks as novel innovation indicator, Research Evaluation, 12(2), 149-156.

Schmoch, U., \& Gauch, S. (2009). Service marks as indicators for innovation in knowledge-based services. Research Evaluation, 18(4), 323-335.

Skålén, P., Gummerus, J., Koskull, C. v., \& Magnusson, P. R. (2014). Exploring value propositions and service innovation: $A$ service-dominant logic study. Journal of the Academy of Marketing Science, 137-158.

Somaya, D., \& S. J. H. Graham, (2006). Vermeers and Rembrandts in the Same Attic: Complementarity between Copyright and Trademark Leveraging Strategiesin Software. SSRN working paper. Available at: http://papers.ssrn.com/sol3/papers. cfm?abstract_id=887484.
Varoğlu, A.K., \& Köker, A.R. (2009). The Relationship between the Degree of innovation and the development Level of a Country. In: Neslihan Aydoğan editors. Innovation Policies, Business Creation and Economic Development: A Comparative Approach (International Studies in Entrepreneurship). Springer: NewYork: 51-62

WIPO (2004). Intellectual property handbook. Available at: https://www.wipo.int/edocs/pubdocs/en/intproperty/489/wipo_pub_489.pdf 